\title{
Analysis on causes of deforestation and forest degradation of Dang district: using DPSIR framework
}

\author{
Krishna Dev Hengaju ${ }^{1^{*}}$ and Ugan Manandhar ${ }^{2}$ \\ ${ }^{1}$ School of Environmental Science and Management, Pokhara University (affiliated), Kathmandu, Nepal \\ ${ }^{2}$ World Wildlife Fund, Kathmandu, Nepal
}

\begin{abstract}
Forests play a prodigious significance in many aspects. It is home to sundry species that exist on earth. Further, forest plays vital role as sinks of $\mathrm{CO}_{2}$ and has been estimated that standing forests sequester about $20 \%$ of global $\mathrm{CO}_{2}$ emission. However, deforestation and forest degradation (D \& D) has been continued to be a major global environmental problem. The study was focused on identifying the causes of $D \& D$ of Dang district using the Drivers - Pressures - State - Impacts Responses (DPSIR) framework. A detailed review of relevant and existing literatures about the study area was done and also field observation and survey was carried out during the study in different village development committees (VDCs) of Dang district. Data and information collected were used for preparing the DPSIR model framework making the DPSIR key words table and DPSIR map. The VDCs were identified by comparing the land use land cover map of Dang district of 2000 and 2010. The study reveals that main causes of $D$ \& $D$ in Dang District are forest encroachment, population growth, forest fire, urbanization, infrastructure development, illegal harvesting of forest resources, etc. It is causing a serious impact on environment. In order to overcome with the situation, government, with an effort from community people, has started awareness programs and many other activities under forest management programs.
\end{abstract}

Key words: Population Growth, Forest Fire, Forest Encroachment

\section{Introduction}

Forest provides a wide range of regulating, cultural and supporting services for human well- being collectively known as ecosystem services (FAO, 2009). It influences local, regional, and global climates. Forests are vital to global carbon cycle. In a developing country, most of the people from $r$ ural communities depends upon the natural resources, mainly forest, for ener gy, drinking water, employment and daily livelihood resources. F orests are declining at faster rate due its commercial values for timber, fuel wood, land for grazing and human settlement. People are forgetting its ecological importance and concerned only to its commercial values. Consequently, there showed various hazards and impacts on earth lik e climate change, global war ming, sea level rise, pollution, and many mores. From 1990 to 2008 a total of 0.7 million hectares of forest has been lost globally (FAO, 2010).

Deforestation and forest degradation are one of the major problems that the world is facing. The sustainability of forest ecosystem requires careful management, efficient utilization and effective protection measures against deforestation and forest degradation (FAO, 2009). Among various countries of the Asia - Pacific region, South and East Asian countries are facing similar situation of rapid

*Corresponding author, email address: krishd.hju@gmail.com deforestation and forest degradation (Pandey et al., 2013). Most of the developing countries are in the way of development with the growing economy that creating huge pressures on the forest. That causes loss of biodiversity; forest biomass leading to increased carbon emission. Global emission for deforestation and forest degradation alone contribute between 20 and $25 \%$ of all greenhouse gas emissions (Sedjo \& Sohngen, 2007). The forest has come up in topic over the years, not for its majestic beauty but for what has been occurring there, the removal and replanting of its prime sources; the trees (Falla, 2014).

Deforestation refers to complete loss of forest cover . Forest degradation relates to loss of biomass (carbon) and reduction in the capacity of forests to produce ecosystem services (WWF, 2013). The types of drivers of deforestation and forest degradation have great influence on the forest carbon impacts and the choice of data sources and methods used to measure and monitor them (Kissinger et al., 2012). For the most part, forest degradation in Nepal takes place as a precursor to deforestation (UNDP, 2014). Recently, the study car ried out by Forest Resource Assessment revealed that 16400 ha of Terai forest has been shrinks in a decade 
(2001 - 2010), which means the Terai forest is degrading at the rate of $0.44 \%$ annually (FRA/DFRS, 2014). Understanding humaninduced causes of deforestation and forest degradation in different social, economic and ecological contexts is one of the $\mathrm{k}$ ey and contentious questions in environmental change research (WWF, 2013).

After several meetings and negotiation processes, to address the deforestation and forest degradation, the concept of RED was emerged during COP-11 (Montreal 2005) and formally introduced during the thirteenth Conference of the Parties to the UNFCCC (COP-13) held in Bali, Indonesia in 2007, agreed on roles of deforestation and forest degradation to reduce the rate of climate change. Now with incorporation of 'F orest conservation and sustainable management of forest and enhancement of carbon stock' into REDD in COP-15 (Copenhagen 2009). Then concept of REDD + came in scene. Nepal being one of the member countries of FCPF since 2008, has already initiated many activities towards the REDD+ readiness in Nepal.

\section{Materials and methods \\ Study Area}

Dang district is located in an inner Terai district in Rapti zone, midwestern region of Nepal with an area of 2955 square kilometer (Fig. 1). It lies in between N $27^{\circ} 37^{\prime}$ to N $28^{\circ} 29^{\prime}$ latitude and $\mathrm{E} 82^{\circ} 2^{\prime}$ to $\mathrm{E} 82^{\circ} 54^{\prime}$ longitude. The District share boundary with the Uttar Pradesh of India in South, Pyuthan, Arghakhachi, Kapilvastu district in East, Salyan, Pyuthan, Rolpa districts in North, and in west Banke and Salyan districts. Geographically, it has the plain of inner Terai also called dun valley, is surrounded by the small Churia hills and the Mahabharata range that formed the two big valleys viz. Dang and Deukhuri Valley. Dang Valley is one of the biggest valleys of Nepal and it is one of the biggest among Asia. Rapti and Babai are the two main rivers of the district with many other small rivers, rivulets and streams.

Around two-third of the total area of Dang is covered by forest. Due to altitudinal variation from 218 to $2058 \mathrm{~m}$, it has different types of forest viz. pure Sal (Shorea robusta) forest, mixed Sal forest, mixed Khayer, mixed Sissoo, Pine forest, Quercus and Rhododendron forest.
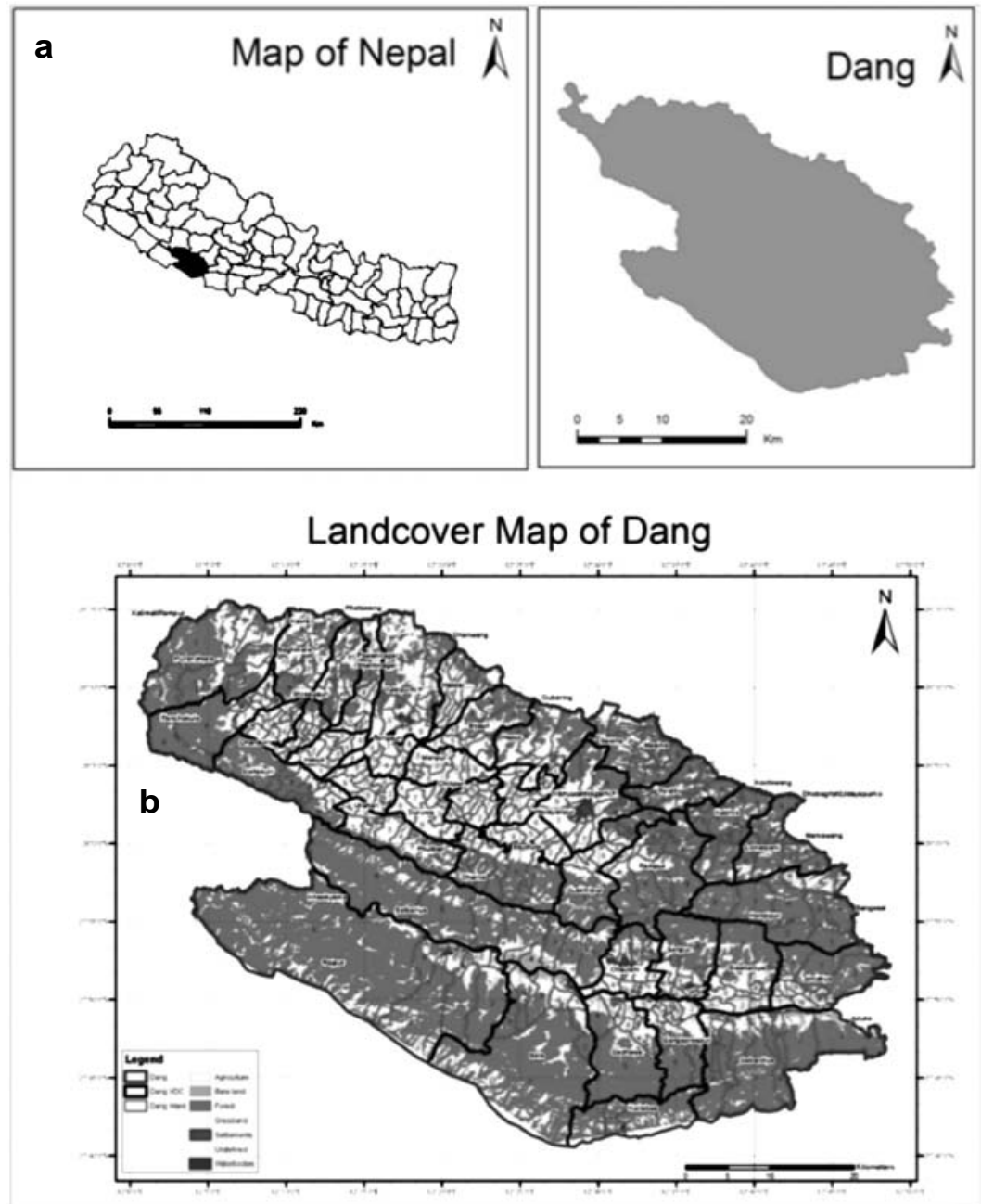

Fig. 1 Map showing the study area (a) and its land cover (b) 


\section{Methods}

The surveyed VDCs were selected on the basis of changes in land use land cover map of 2000 and 2010 A .D. of Dang district and consultation with officials and local people. Six representative VDCs were selected for FGDs, KIIs and Questionnaire survey that covers Plain Terai joined with Indian border: Rajpur and Bela VDCs, Deukhuri Valley: Satbariya and Gobardiya VDCs, Dang V alley: Gorahi Municipality and Saidha VDC. Field observation was carried out in the whole district for the verification and validation of primary and secondary data that were collected. To determine sample size of the sur vey, a probability technique was applied given by Arkin \& Colton (1963). The research was conducted based on the objectives to identif y the causes of deforestation and forest degradation. Drivers - Pressures - States - Impacts - Responses (DPSIR) framework was intensively used. The research design of the study was illustrative, analytical and descriptive.

\section{Model specification DPSIR framework}

The DPSIR framework is a flexible framework or a tools for analyzing the environmental problems that assists many decision making processes. The DPSIR framework is the modification of the PressureState-Response (PSR) model (Goll II et al., 2014). They also reported that it was initially developed by the Organization for Economic Co-operation and Development (OECD) to structure its work on environmental policies and reporting. L ater the European Environment Agency (EEA) proposed and widely adopted the use of the DPSIR framework, which distinguished driving forces, pressures, states, impacts and responses. Data collected were presented in the table of DPSIR with the main keywords and then a DPSIR map was prepared showing the interrelationship between these five components.

\section{Result and discussion}

From the household questionnaire survey the general information about their socio-economic status of the community , their dependency on the forest and the root causes of the deforestation and the forest degradation were collected (Table 1). Besides, the evidences and the information were collected from the reports, literature, DDCs profile and relevant documents (Table 2).

After the extensive field observation, household questionnaires, KIIs, FGDs, consultation with different concerned stakeholders, experts and going through various literature of Dang district; the major drivers, pressures, state, impacts and responses that are causing deforestation and forest degradation were reck oned. Though the forest area of Dang district is in increasing trend compare to other $\mathrm{T}$ erai districts, deforestation and forest degradation is an imminent issue. Here, the proximate and underlying causes of deforestation and forest degradation is discussed and analyzed using DPSIR Framework.

\section{Drivers of Deforestation \& Forest Degradation Population growth}

The study area has increasing population at the growth rate of $1.78 \%$ (CBS, 2013). Increasing population demands the daily livelihood resources in the same rate. Although cor relating demographic change with forest use pattern is difficult, it is widely believed that population can affect deforestation in different ways, including changes in the number of rural families seeking land to cultivate, fuel wood or timber; and demand for agricultural and forest products (WWF, 2013). Land is fixed and not extendable assets. So with this growing population, if these assets are not managed properly it may bring ver y serious problems. F rom agriculture land to grazing land, energy sources to construction materials, salary based services to daily wages labour work, for each and every step of life people depends on forest.

\section{High dependency on forest products}

The result showed that majority of the people depends on the fuel wood (52.6\%) (Table 1) for cooking foods. Not only the fuel wood, people depends on forest for grass, fodder for the domesticated animals. More than 180 industries here are dependent

Table 1 Major outlining factor playing roles in causing D \&D

\begin{tabular}{|c|c|c|c|c|c|}
\hline Main Occupation & $\%$ & Means of cooking & $\%$ & No. of livestock's & $\%$ \\
\hline Agriculture (Ag) & 42.1 & Fuel wood only (FW) & 52.6 & $0-5$ & 31.6 \\
\hline Business & 15.8 & Biogas only (B) & 2.6 & $5-10$ & 23.7 \\
\hline Foreign Employment & 5.3 & LPG gas only (L) & 7.9 & $10-15$ & 7.9 \\
\hline Service $(S)$ & 28.9 & FW \& B 15.8 & $>15$ & 10.5 & \\
\hline $\operatorname{Ag} \& S$ & 7.9 & FW \& L 13.2 & None & 26.3 & \\
\hline Means of feeding livestocks & $\%$ & $\begin{array}{l}\text { Distance from nearby } \\
\text { forest (meter) }\end{array}$ & $\%$ & Cause of D \&D & $\%$ \\
\hline Open grazing & 34.2 & $0-200$ & 47.4 & Illegal logging & 21.1 \\
\hline Stall feeding & 18.4 & $200-400$ & 23.7 & Forest fire & 21.1 \\
\hline Both & 18.4 & $400-600$ & 10.5 & Overgrazing & 5.3 \\
\hline- & - & $>600$ & 10.5 & Forest encroachment & 31.6 \\
\hline- & - & - & - & Others21.1 & \\
\hline
\end{tabular}

Source: Field Survey (2014) 
on forest (Table 2). Moreover, forest is only the source for timber which is used for constructing houses and many other purposes. Excessive extraction of forest products to meet persistently high demands for fuel, timber, fodder and other forest products are the major causes of deforestation and forest degradation in most parts of the landscape (WWF, 2013). With the cur rent rate of population growth, supply of firewood is never expected to meet demand. There will be continued shortage in the Terai region due to the high demand and population growth (MoFS C, 2014). Increased population growth, over dependency in forest, high number of livestock rearing ( $76.7 \%$ people rear livestock) people and poverty will always lead to deforestation and forest degradation in Nepal (Table 1)

\section{Occupation}

The most of the people of study area depend on agriculture (42.1\%) and they also engaged in animal husbandry, daily wages activities and other services and profession (Table 1). Increasing population demands more food and shelter . So people are encroaching the forest to expand their agriculture land slowly . Expansion of cultivation into forest areas to meet spiralling demands for agricultural land is a major driver of deforestation in almost all parts of the landscape (WWF, 2013). Agriculture is estimated to be the proximate driver for around $80 \%$ of deforestation worldwide. (Kissinger et al., 2012).

\section{Natural hazards and forest fire}

Forest fire is one of the major drivers of deforestation causing destruction of hectares (ha) of forest in a blink. According to district forest office report, Dang, due to natural hazards lik e continuous and concentrated rainfall and forest fire, 117.86 ha of forest area has been degraded with 3,977 number of trees and

Table 2: Evidence of causes of D and D and responses

Natural hazards (continuous and concentrated rainfall) and Forest fire

Illegal and unsustainable harvesting practices

Forest dependent industries

Forest encroachment

Forest handover to Community in different budget year (2045 B.S - 2068 B.S)

Renewable Energy technologies installed by AEPC ( 2011 - 2013)
30,698 saplings have been destroyed (Table 2). Fire is the most important factor for shaping vegetation composition and leading to succession. It becomes problem when they occur in wrong time, wrong place and wrong magnitude. Uncontrolled forest fire is an important driver of forest degradation throughout the landscape, particularly in the Siwaliks (WWF, 2013). Recur rent forest fires severely damage and prohibit regeneration and growth of seedlings, destroy non-timber forest products and, in some cases, encourage invasive species (WWF, 2013).

\section{Policy failure}

Forest policies formulations are very important for the management of forest resources; although the execution of existing policies is also significant. Lack of effective implementation of forest policies encourages people to do more forest related crime lik e illegal logging, forest encroachment, etc. From 2064 B.S to 2069 B.S, 69 cases of illegal logging has been reported and 182 people were involved in it (Table 2). Though, the study area has many forest related polices, laws and regulations to gover $\mathrm{n}$ the forest and environment, it has always remains a great challenge for the full implementation of these legal framework. Because more than 180 industries in the study area are forest dependent and daily income of people depends on those industries (Table 2).

\section{Political instability}

During the insurgency period, the rate of deforestation and forest degradation was at very high rate. At that time, life of people was at priority list than the forest. So people from hilly areas lik e Rukum, Rolpa, Salyan and Arghakhachi come here in search of safe place to settle. Many hectares of forest areas were encroached at that time (Table 2). Army and the Maoist only cut 40 ha of forest area for the camping (Table 2). Forest is the only places for them to hide. Implementation of forest polices, rules and regulation at that time was very challenging.

\begin{tabular}{|c|c|}
\hline Natural hazards (continuous and concentrated rainfall) and Forest fire & $\begin{array}{l}\text { Forest area degradation: } 117.86 \text { ha } \\
\text { Number of trees destroyed: } 3977 \\
\text { Number of saplings: } 30698 \\
\text { Number of dead wildlife: } 1 \text { hyena (DFO, 2014) }\end{array}$ \\
\hline Illegal and unsustainable harvesting practices & $\begin{array}{l}\text { Number of cases reported (2064 - 2069): } 69 \\
\text { Number of people involved: } 182 \text { (DFO, 2013) }\end{array}$ \\
\hline Forest dependent industries & $\begin{array}{l}\text { Furniture industries: } 95 \\
\text { Small saw mill industries: } 35 \\
\text { Brick factories: } 20 \\
\text { Others: } 34 \text { (DFO, 2013) }\end{array}$ \\
\hline Forest encroachment & $\begin{array}{l}\text { Before 2047: } 108 \text { places, } 16144.4 \text { ha, } 2465 \text { houses } \\
\text { After 2047: } 119 \text { places, } 1094.65 \text { ha, } 3600 \text { houses (DFO, 2013) } \\
\text { By Army, Maoist Army and Police: } 3 \text { Places, } 40 \text { ha }\end{array}$ \\
\hline Forest handover to Community in different budget year (2045 B.S - 2068 B.S) & $\begin{array}{l}\text { Total Number: } 481 \\
\text { Total Area: } 98902.79 \text { ha (DFO, 2014) }\end{array}$ \\
\hline Renewable Energy technologies installed by AEPC ( 2011 - 2013) & $\begin{array}{l}\text { Number of Biogas installed: } 2923 \\
\text { Number of Solar Heating Stove (SHS): } 2619 \\
\text { Number of Improved Cooking Stove (ICS) with metallic ICS: } \\
4022 \text { (AEPC/ESAP, 2013) }\end{array}$ \\
\hline
\end{tabular}




\section{Pressures}

The above drivers of deforestation and forest degradation exert pressures on the forest and environment. Pressures exerted are generally caused due to human activities.

\section{Forest encroachment}

Forest encroachment is one of the major pressures exerted by human that is creating a very big problem in the study area. With the increase in infrastr ucture development and the migration from hill and the high demand of NTFPs are the reasons behind forest encroachment. Generally, the forest encroachers are the hill migrants from the neighboring districts lik e Rukum, Rolpa, Salyan and Arghakhachi. Likewise, for the resettlement of the freed 'Kamaiyas' (bonded labor), the forest land is being distributed (Photo 1). In the name of freed Kamaiyas, landless and the migrants; rebellions groups and organization, many forest area are being encroached (Table 2).

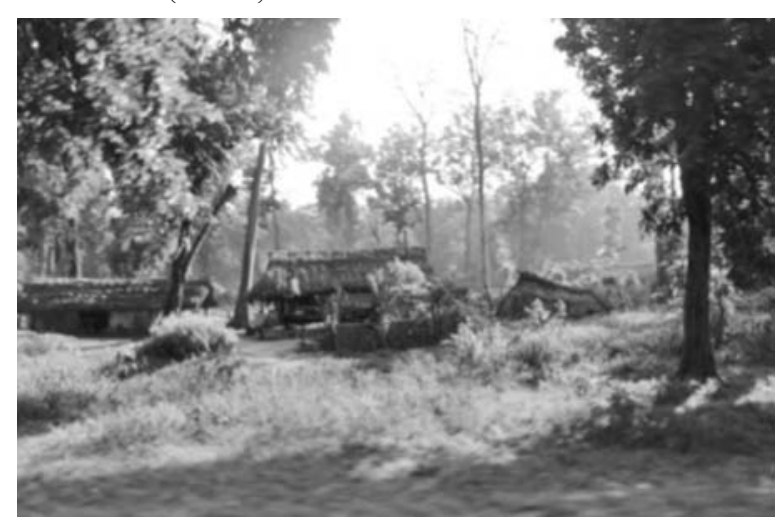

Photo 1 Freed Kamaiyas and hill migrants settlement in forest area

\section{Migration and resettlement}

During the insurgency period many people from hill migrated in the district for safety. People from hill migrate here in search of employment, opportunities, services and so on. Mostly the hill migrant from the neighboring districts like Rukum, Rolpa, Salyan and Arghakhachi comes in the study area like Satbariya, Lalmaitiya, Gadhawa, Sishaniya, Rajpur. Also there is an open/ free border relation with the neighboring country, India. People from India make a marriage relation with the districts and stayed there for some period. Later, they make small huts by encroaching the forest area and get settled permanently. They later expanded the agriculture land.

\section{Infrastructure development}

Development is unavoidable. Although fuelwood is primarily used for domestic purpose, it is increasingly being consumed in the industrial sector, mainly by brick factories, hotels and manufacturing of alcohol (MoFSC, 2014). Most of the development projects have led in destruction of forest area. Development of the road network has been a priority development objective in recent years, particularly at local levels (MoFS C, 2014). Road constr uction, irrigation project, hospitals, schools, etc. had led tremendous area of forest into destruction.

\section{Forest dependent industries}

According to the nature of industries, the forest products lik e timber, NTFPs, herbs, etc. are being demanded. There are 95 furniture industries, 35 small saw mills, 7 veneer, 20 brick, 7 NTFPs production and many other industries and factories are operating recently (Table 2). These all factories and industries get the raw materials from forest. It is ver y necessary to keep the balance between the forest ecosystem and the industries and factories.

\section{Illegal and unsustainable harvesting practices}

People have the habit of easy and fast money making, they involved in timber supply, illegal cutting, poaching of wildlife (Photo 2). People can earn NRs 1,500 within an hour if they can bring timber from the forest. So people are fascinated towards the easy money making. Between 2064 and 2069 B.S., 69 cases has been reported and 182 people were involved in illegal logging (Table 2).

\section{Urbanization}

Urbanization is the index of development. It helps in increasing the land value. With the increasing population and infrastructure development, the demand of mark et and economy is growing rapidly. People are also migrating from different parts of rural hill areas in search of many opportunities. It is influencing and pressurizing the rural settlement. There is two municipalities in Dang namely Gorahi and T ulsipur. In order to deal with the increasing population and their demands, forest resources are being used unsustainably.

\section{Free grazing and overgrazing}

Though people of the study area have not many domesticated animals (maximum 31.6\% household have $0-5$ and only $10.5 \%$ have more than 15 livestocks) (Table 1), the feeding practices are exerting pressure that causes deforestation and forest degradation. The result shows that $34.2 \%$ people graze their livestock freely in forest, stall feeding is very less in practice (Photo 3).

\section{State}

Pressures exerted by human activities leads to the change in state of the forest of Dang district. The change in forest cover is causing decrement or loss of biodiversity. Dang district is the source of many NTFPs and herbs. It is a home to mega species lik e Royal Bengal Tiger and many other endangered species of both flora and fauna. Some part of the forest of Dang is in protected areas, i.e. Banke National Park and its buffer zone.

\section{Decrease in forest quality}

Because of repeated forest fires, different natural calamities, free grazing of domesticated animals, the quality of forest is slowly degrading. Illegal har vesting and unsustainable har vesting practices caused the degradation of quality of forest. Because of the disturbance in the forest ecosystem, the forest becomes stagnant and there is no regeneration. Thus, the forest area is slowly converting into shrub land. 


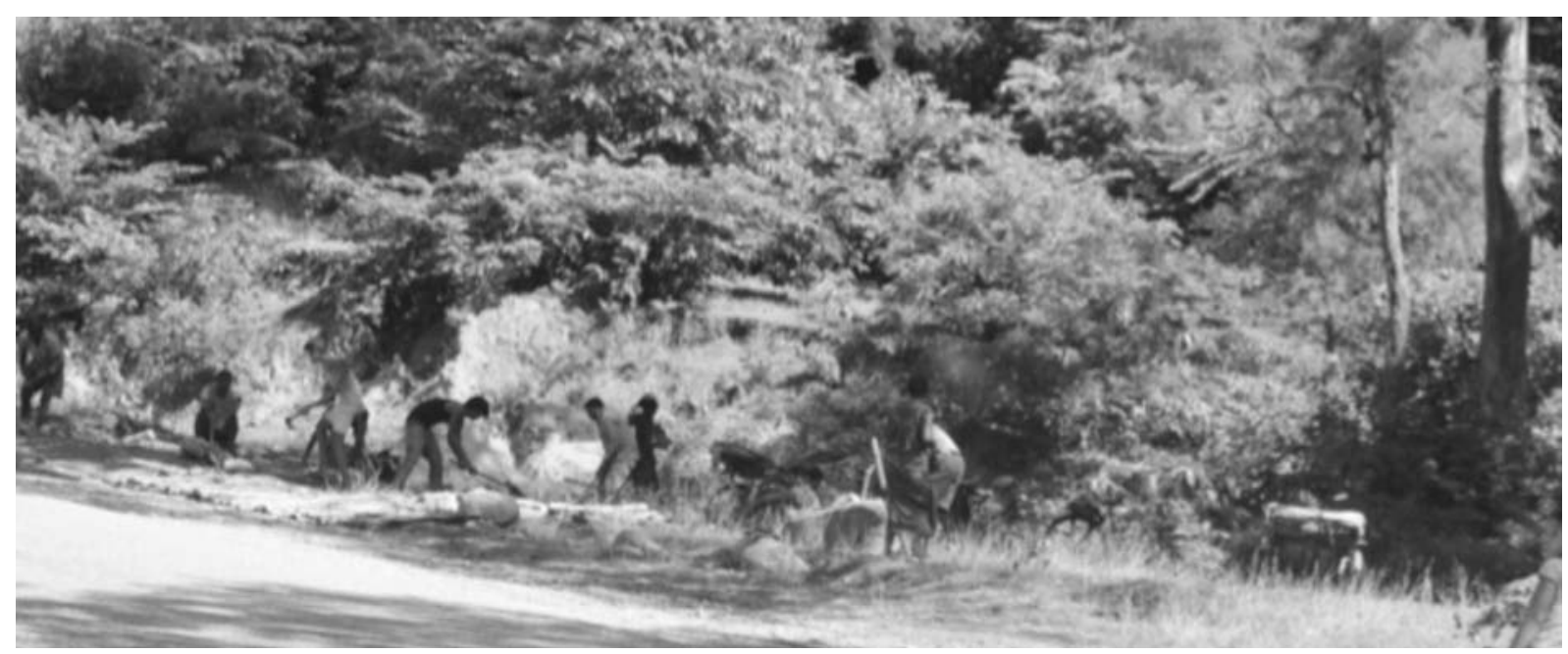

Photo 2 Illegal harvesting of forest product near highway

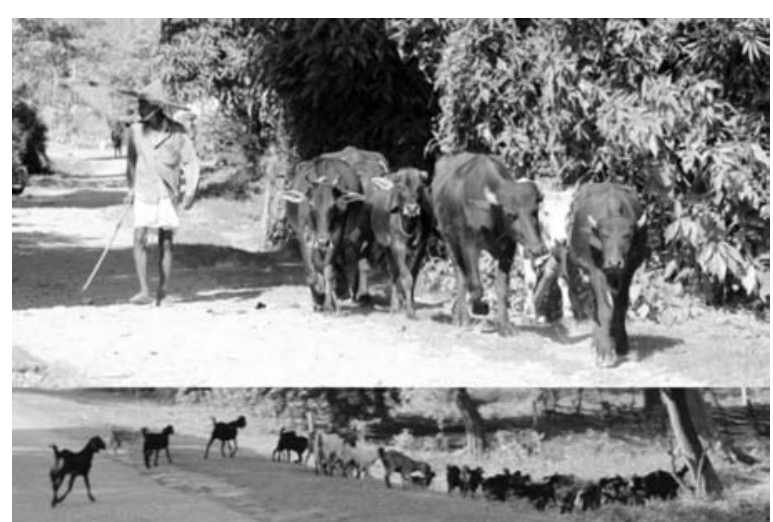

Photo 3 Free grazing in the forest area

\section{Degradation of land and loss of forest ecosystem and services}

Many factors interrelating with each other are impacting the forest ecosystem and services. The natural calamities like floods, landslides (Photo 4) and also the human induces disasters like forest fires, and also forest encroachment causes degradation of both agriculture and forest area. River cutting and sedimentation due to flood and landslides are the major problems to agriculture land resulting into change in composition of forest.

\section{Human wildlife conflict}

Annually, more than 10 million Nepali cur rencies is contributed to country's GDP from this district that all depends upon forest resources (DFO, 2014). The forest is also home to the mega species like Royal Bengal Tiger . But, due to the increasing human population and many other factors, forest area has been converted to agriculture land and shrub land.

\section{Responses}

In order to deal with the problems of deforestation and forest degradation, the authorities of Dang district lik e district forest

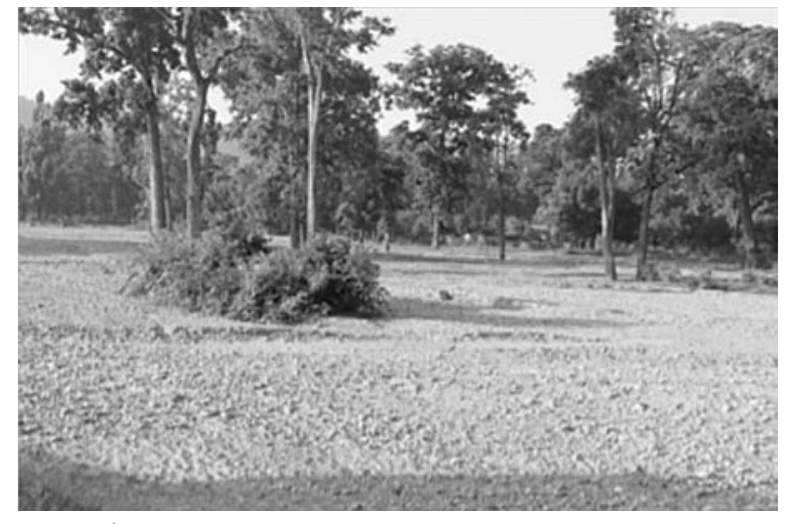

Photo 4 River degrading forest area

office, communities and other sectors have responded the problems in several ways;

- Capacity building

- Awareness, trainings and education

- Monitoring unit

- Forest management programs

- Alternative energy promotion

\section{Rules, regulation and polices}

Although there are many existing $r$ ules and policies, GoN has again emphasized on the Chure conservation policy. The policies tried to identify the upstream (Chure and Bhabar) and downstream (plain Terai) area and interlinked the upstream and downstream area with the introduction of Payment for Ecosystem ser vices, that helps in balancing the ecosystem. The policies support for the upstream conservation program and downstream sustainable management of forest. Many $r$ ules, regulation and policies are there to support the conservation and sustainable management of forest like, Forest Act, 2049 B.S. and Forest Regulation, 2051 B.S.; National Parks and Wildlife Conservation Act, 2049B.S. and 
its Regulation; Land and Watershed Conservation Act., 2039 B.S. and its Regulation; 2042 B.S., Environment Conservation Act, 2053 B.S. and its Regulation, 2054 B.S.. Similarly, Collaborative Forest with Business Motive Work Plan 2068 B.S., Forest Encroachment Control Plan 2068 B.S., Protected forest management related plan, Master Plan for F orestry Sector 2066 B.S., District F orest Coordination Committee establishment and operation guidelines, Environment Protection guidelines and others. Lik ewise, Government forest handedover to community has also supported the forest conser vation. There are 481 forests with an area of 98,902.79 ha has been handedover to community in different fiscal years from 2045 B.S to 2068 B.S. (Table 2). The handover of forest has brought feeling of ownership in the community and they are protecting and improving the forest in Dang. The district forest office, Dang is planning to give the forest area to the industries, factories as a collaborative forest with a motive to increase the forest area and with a motive to generate more employment opportunities to the local people.

\section{Forest management programmes}

Plantation programmes in the different government barren land and river bed, school, gover nment and open community area. Collaborative forestry management with different private sectors has also been planned. Litter picking, forest thinning activities, bamboo plantation and different forest conser vation activities programs has been practiced in Dang district. Forest fire control activities, nursery operation and seedling production, forest resources utilization programme, regular monitoring by district unit, community forest group, anti-poaching unit, etc. has been conducted.

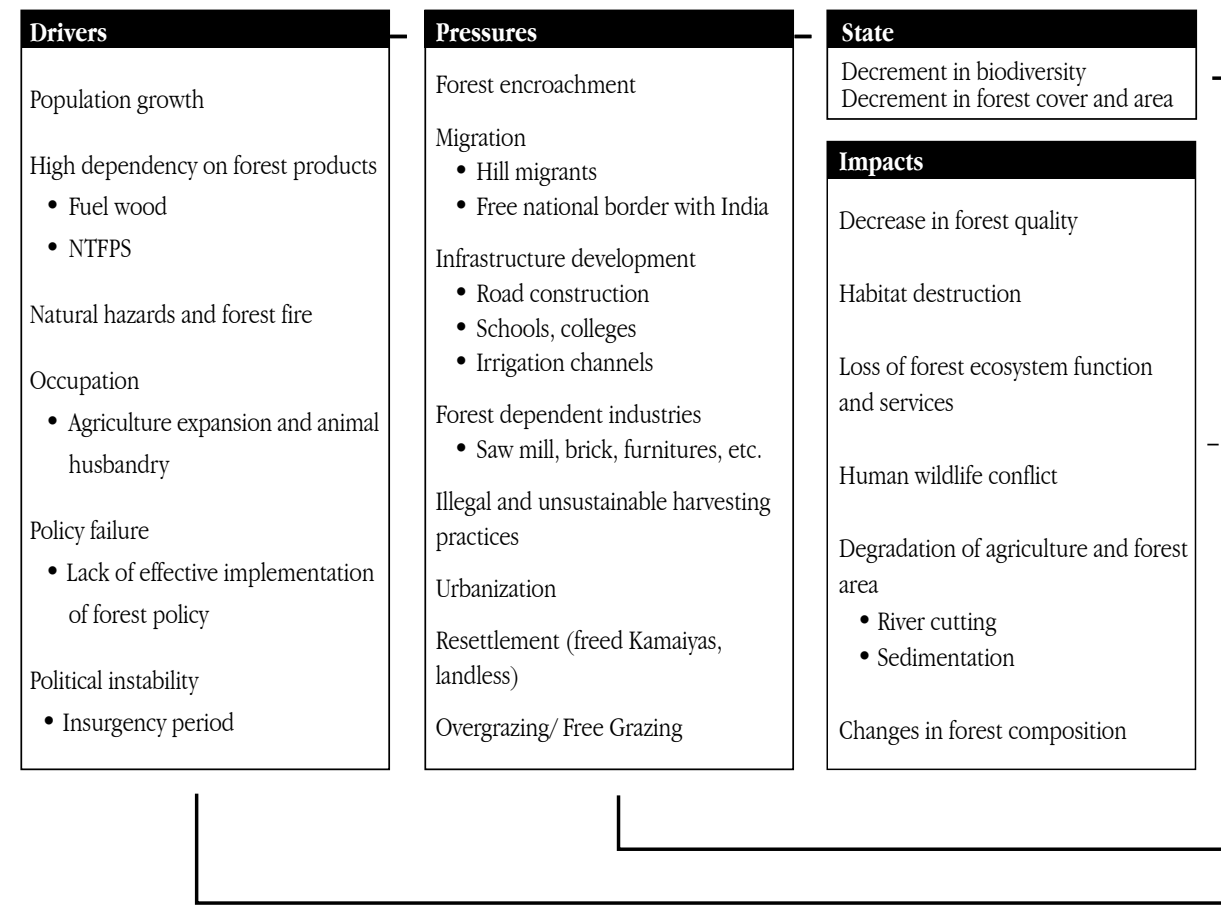

Fig. 2 DPSIR Map interlinking with five different components.

\section{Alternative energy promotion}

With a motive to decrease the pressure on forest for fuelwood, renewable energy technologies like solar, biogas have been installed. Moreover, fuel efficient technologies like ICS \& MICS have been installed (Table 2). The inter relationship between the different five components of deforestation and forest degradation is presented in Fig. 2.

\section{Conclusion}

The present study showed that population growth, high dependency on forest products, traditional occupation, political instability, policy failure, etc. are the major divers of D \& D in Dang district. Forest encroachment is linked with many drivers and pressures itself. For fuel wood, shelter or for expansion of agriculture land, forest is being encroached. Similarly, illegal logging and unsustainable harvesting for forest resources like fuelwood, timber, NTFPs and other medicinal plants are also playing important role. Other activities interlinked are infrastructure development, forest fire, resettlement for freed $\mathrm{K}$ amaiyas and landless, urbanization, etc. F orest area is slowly in decreasing and in degrading condition. Forest composition is changing; forest area is turning to shrub land, habitat destruction of wildlife, etc. are the major impacts caused due to deforestation and forest degradation.

In order to address the problems of causative factors of deforestation and forest degradation and to deal with the impacts caused, different activities have to be carried out. In addition, the existing plans and policies should be implemented strictly and properly to ensure the conservation and promotion of forest and environment.

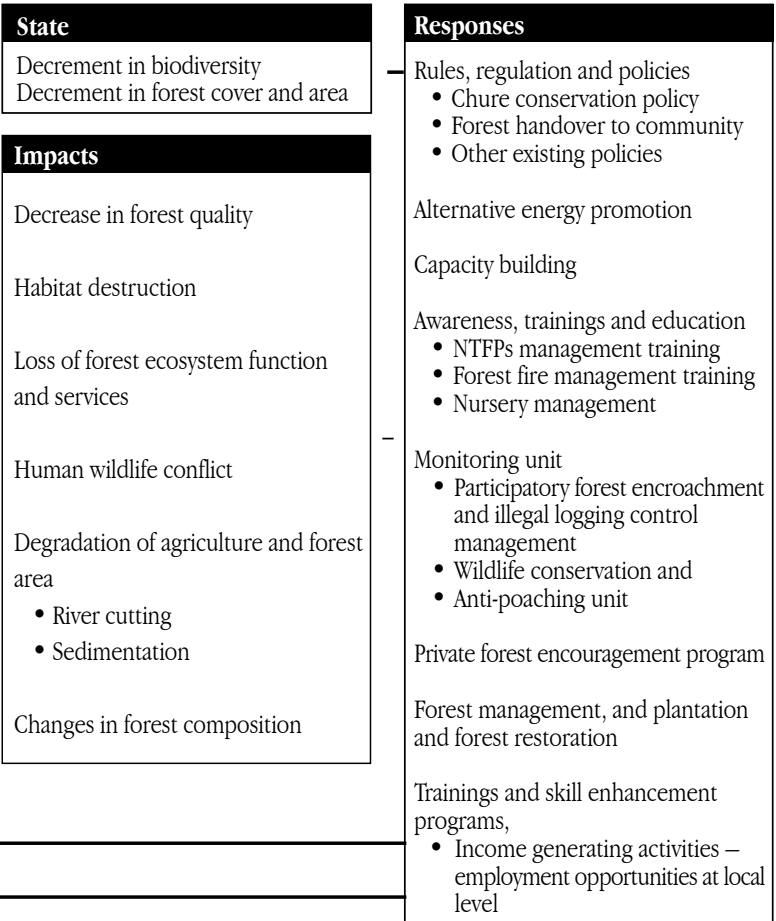




\section{Acknowledgements}

The authors are grateful to School of Environment Science and Management, Kathmandu for granting permission for this study. Our special thanks goes to WWF -Nepal for providing financial support, Ajaya Bhakta Mathema and Bhupendra Shar ma for academic and administrative support during entire study period, Mithun Bista for assisting the field work, Pankaj Bajrachar ya for preparing land-use, land-cover map. We would also like to thank all the officials and people of Dang district for their active participation and support during the study period.

\section{References}

AEPC/ESAP. (2013). Renewable Energy Data Book. Government of Nepal, Ministry of Environment.

Arkin, H., \& Colton, R. (1963). Table of statistics. Newyork: Barnes and Noble.

CBS. (2013). District Profile. Dang.

CBS. (2013). Environment Statistics of Nepal - 2013. Government of Nepal, National Planning Commissiona Secretatariat.

CBS. (2013). Statistical Year Book of Nepal - 2013. Government of Nepal, National Planning Commission Secretariat.

DDC. (2015). Disctrict Development Plan 2015/2016. Dang.

DFO. (2013). District Forest Annual Report. Dang.

DFO. (2014). District Forest Management Five Year Plan . Dang.

Falla, K. (2014). Deforestation and Afforestation, the value of a forest; Causes, Effects and Possible Solutions.

FAO. (2009, December). Case Studies on Measuring and Assessing Forest Degradation. Forest Resources Assessment Programme Working Paper, working paper 163.

FAO. (2010). Global Forest Resources Assessment Report 2010, Main Report. Rome FAO.

FRA/DFRS. (2014). Churia Forests of Nepal. Forest Resource Assessment Nepal, Department of Forest Research and Survey. Babarmahal, Kathmandu: Department of Forest Research and Survey.
FRA/DFRS. (2014). Terai Forests of Nepal (2010 - 2012). Babarmahal, Kathmandu: Forest Resource Assessment Nepal Project/ Department of Forest Research and Survey.

Goll II, N. B., Li, J., McKay, J., \& John, S. (2014, March). Analysis on the Causes of Deforestation and Forest Degradation In Liberia: Application of the DPSIR Framework.

Kissinger, G., Herold, M., \& De Sy V. (2012). Drivers of Deforestation and Forest Degradation: A Synthesis Report of REDD+ Policymakers. Vancouver, Canada: Lexeme consulting.

Lambien, E. F., Geist, H. J., \& Lepers, D. (2003). Dynamics of land use and land cover change in tropical regions. Annu: Rev Environ Resour, 28.

MoFSC. (2014). People and Forests - An SMF- Based Emission Reduction Program in Nepals Terai Arc Landscape, March 7, 2014, ER-PIN submitted to the FCPF Carbon Fund. Ministriy of Forests and Soil Conservation, Government of Nepal.

MoFSC. (2014). Understanding drivers and causes of deforestation and forest degradation in Nepal: Potential policies measures for REDD+. Kathmandu: Government of Nepal.

Pandey, S. P., Cockfield, G., \& Maraseni, T. N. (2013). Major Drivers of Deforestation and Forest Degradation in Developing Countries and REDD+. Int.J.for Usuf. Mngt(14 (1)), 99 - 107.

Sedjo, R. A., \& Sohngen, B. (2007). Carbon Credits for Avoided Deforestation. Resources for the Future, Discussion paper 07 - 47. Washington, DC.

UNDP. (2014). Area of forest under sustainable management: Deforestation and degradation Retrived from bttp://www.bipindicators. net/forestdegradation. Biodiversity indicators partnership.

WWF. (2013). Drivers of Deforestation and Forest Degradation Chitwan - Annapurna Landscape. WWF Nepal, HariyoBan Program. 